Andrei A. Orlov

Milwaukee, Wisconsin, USA

\title{
THE HEIRS OF THE ENOCHIC LORE: "MEN OF FAITH» \\ IN 2 ENOCH 35:2 AND SEFER HEKHALOT 48D:10
}

Make public the twenty-four books that you wrote first and let the worthy and the unworthy read them; but keep the seventy that were written last, in order to give them to the wise among your people. For in them is the spring of understanding, the fountain of wisdom, and the river of knowledge.

4 Ezra 14

\section{Enoch and Moses}

Chapter 35 of 2 (Slavonic) Enoch, a Jewish apocalypse apparently written in the first century CE, unveils the story of the transmission of the Enochic scriptures and their important role in the last generation. ${ }^{2}$ In 2 Enoch 35:1-3 the Lord gives Enoch the following instruction about the destiny of his handwritings:

And I will leave a righteous man from your tribe, together with all his house, who will act according to my will. And from his seed another generation will arise, the last of many, and very gluttonous. Then at the conclusion of that generation the books in your handwriting will be revealed, and those of your fathers, and the earthly guardians (стражие Земкии) [of these books] will show them to the Men of Faith (моужемь вњрмъым).

${ }^{1}$ Part of this paper was read at the Annual Meeting of SBL/AAR, San Antonio, 23-26 November 2004.

${ }^{2}$ A word must be said about the complex nature of the Slavonic text of this chapter. Francis Andersen observes that «very little is claimed for the translation of ch. 35 in either recension. The texts are parallel, but the numerous minor variations and uncertainty over the clause boundaries make all MSS rather unintelligible». He further suggests that «in the present stage of research all individual readings should be kept in mind as options». F. I. AnDERSEN, 2 (Slavonic Apocalypse of) Enoch // OTP. Vol. 1. 158. A close analysis of the Slavonic text in both recensions demonstrates that the shorter recension appears to have preserved the material in a more coherent form. 
And they will be recounted to that generation, and they will be glorified in the end more than in the beginning. 2 Enoch 35:1-3 (shorter recension). ${ }^{3}$

The important detail of this account is that the transmission of the Enochic scriptures on earth will enable the earthly guardians of the books to convey the patriarch's writings to the Men of Faith (моужемь вњрмым ). ${ }^{4}$ The reference to the group «Men of Faith» as the last link in the chain of transmission of the Enochic scriptures is important for connecting the Slavonic apocalypse with the later Jewish mysticism since it attests to the terminology found in Sefer Hekhalot, also known as 3 Enoch, a later Enochic text, preserved in a corpus of Hekhalot writings. In 3 Enoch 48D:10 (Synopse $\S 80$ ) the Torah is initially given by Enoch-Metatron to Moses and then passed through the chain of transmission which eventually brings this revelation into the hands of the group designated as the Men of Faith. The passage reads:

Metatron brought Torah out from my storehouses and committed it to Moses, and Moses to Joshua, Joshua to the Elders, the Elders to the Prophets, the Prophets to the Men of the Great Synagogue, the Men of the Great Synagogue to Ezra the Scribe, Ezra the Scribe to Hillel the Elder, Hillel the Elder to R. Abbahu, R. Abbahu to R. Zira, R. Zira to the Men of Faith, and the Men of Faith to the Faithful (אפשי אמרנה ראנשי אמרונה

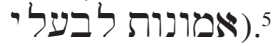

Scholars have previously noted that this succession of the mystical tradition recalls the chain of transmission of the oral law preserved in Pirke Abot, the Sayings of the Fathers. ${ }^{6} \mathrm{~m}$. Abot 1:1 reads:

Moses received the Law from Sinai and committed it to Joshua, and Joshua to the elders, and the elders to the Prophets; and the Prophets committed it to the men of the Great Synagogue. They said three things: Be deliberate in judgment, raise up many disciples, and make a fence around the Law. $^{7}$

${ }^{3}$ М. И. Соколов, Материалы и заметки по старинной славянской литературе. Выпуск третий, VII: Славянская Книга Еноха Праведного / Тексты, латинский пер. и исследование. Посмертный труд автора приготовил к изд. М. СПЕРАНский // ЧОИДР 4 (1910) 1.93.

${ }^{4}$ This expression is attested in the MSS of both recensions. See ibid. 1.35 and 1.93.

${ }^{5}$ P. Alexander, 3 (Hebrew Apocalypse of) Enoch // OTP. Vol. 1. 315; P. SchäFER with M. SCHLÜTER and H. G. von Mutius, Synopse zur Hekhalot-Literatur (Tübingen, 1981) (TSAJ, 2) § 80.

${ }^{6}$ Alexander, 3 Enoch... 315; M. Swartz, Scholastic Magic: Ritual and Revelation in Early Jewish Mysticism (Princeton, 1996) 188.

${ }^{7}$ H. Danby, The Mishnah (Oxford, 1992) 446. 
The Hekhalot writer reworks the traditional Mishnaic arrangement of prophets, rabbis, and sages by placing at the beginning of the chain the figure of Enoch-Metatron, posed there as the initial revealer. As the final heirs of this revelation, he adds an enigmatic group whom he designates as the Men

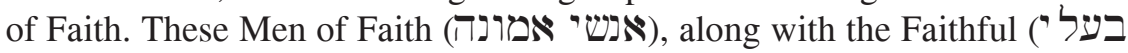
אמונה ${ }^{8}{ }^{8}$ represent the last link in the chain of the transmission to whom the Torah will be eventually handed. This group is unknown in Pirke Abot (PA) and similar clusters of the early traditions attested in Abot d' R. Nathan (PRN). ${ }^{9}$ These designations similar to the one found in 2 Enoch help to strengthen the hypothesis proposed by Gershom Scholem and other scholars that 2 Enoch contains the earliest formulations of Jewish mystical developments.

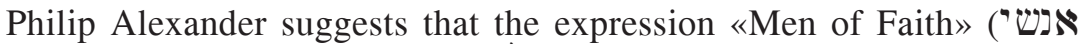
(בעמונה) and the «Faithful» (בעל אמונה) found in Sefer Hekhalot «appear to be quasi-technical terms for the mystics». ${ }^{10}$ Michael Swartz offers a similar hypothesis proposing that the enigmatic Men of Faith and the Faithful, who occupy the last place in the line of transmission in Sefer Hekhalot 48D, may refer to either the mystics themselves or to their mythic ancestors. ${ }^{11}$ Both Alexander ${ }^{12}$ and Swartz note that the term בעל י אמונה appeared among the synonyms for the group of mystics in a hymn in Hekhalot Rabbati. The hymn connects the divine attribute with the designation of the group..$^{13}$

It is intriguing that in 2 Enoch, as in the Hekhalot passage, Enoch-Metatron's revelation will also be handed eventually to the Men of Faith (моужемь вьрмым ). ${ }^{14}$ In light of the Hekhalot evidence, this reference may hold the

${ }^{8}$ Swartz renders this term as the «Possessors of the Faith». See Swartz, Scholastic Magic... 179.

${ }^{9}$ On the chain of tradition in Pirke Abot and Abot d' R. Nathan see: E. BicKerMAN, La chaîne de la tradition pharisienne // RB 59 (1951) 44-54; L. FinKELSTEIN, Introductory Study to Pirke Abot // JBL 57 (1938) 13-50; A. J. SALDARINI, The End of the Rabbinic Chain of Tradition // JBL 93 (1974) 97-106; IDEM, Scholastic Rabbinism: A Literary Study of the Fathers According to Rabbi Nathan (Chico, Calif., 1982).

${ }^{10}$ Alexander, 3 Enoch... 315, note v.

${ }^{11}$ Swartz observes that «it is likely that these terms refer either to the mystics themselves, or, perhaps, mythic ancestors patterned after Elders and the Men of the Great Assembly and influenced by the appearance of terms such as אנשי אמרונה talmudic literature». SwarTz, Scholastic Magic... 188.

${ }^{12}$ Alexander also observes that in the Alphabet of R. Aqiba (A. JellineK, Bet haMidrash. 6 vols. (Jerusalem, 1967) Vol. 3. 29) «"the men of faith" constitute a distinct category of the righteous in the world to come». Alexander, 3 Enoch... 315, note $\mathrm{v}$.

${ }^{13}$ Alexander, 3 Enoch... 315, note v; Swartz, Scholastic Magic... 188.

${ }^{14}$ It appears that the expression found in 2 Enoch 35:2 can be related to both designations since the Slavonic моужемь вњрмъм саn be translated also as the Faithful (men). 
key to the enigma of the early designation of the mysterious group which stands behind the early Jewish mystical speculations reflected in 2 Enoch. It is significant that the designation of the ultimate receptors of the esoteric lore is identical in both traditions. The Hekhalot reference may, therefore, have an Enochic provenance. Despite the fact that the reference to the chain of transmission is repeated several times in the Hekhalot literature, the reference to the Men of Faith and the Faithful in the chain is made only in the «Enochic» passage from 3 Enoch 48D.$^{15}$ It is possible that the author of the passage combines the two traditions by adding to the mishnaic line of transmission reflected in Pirke Abot and Abot de Rabbi Nathan a new Enochic group, similar to those found in 2 Enoch 35. The table below illustrates these combinations:

\begin{tabular}{|c|c|c|}
\hline 2 Enoch 35:2 & m. Abot $1: 1$ & Synopse § 80 \\
\hline $\begin{array}{l}\text { Then at the conclusion } \\
\text { of that generation the } \\
\text { books in your handwrit- } \\
\text { ing will be revealed, and } \\
\text { those of your fathers, }\end{array}$ & $\begin{array}{l}\text { Moses received the Law } \\
\text { from Sinai and committ- } \\
\text { ed it to Joshua, and Jo- } \\
\text { shua to the elders, and the } \\
\text { elders to the Prophets; } \\
\text { and the Prophets commit- } \\
\text { ted it to the men of the } \\
\text { Great Synagogue... } \\
\text {...make a fence around } \\
\text { the Law. }\end{array}$ & $\begin{array}{l}\text { Metatron brought it [To- } \\
\text { rah] out from my store- } \\
\text { houses and committed it } \\
\text { to Moses, and Moses to } \\
\text { Joshua, Joshua to the } \\
\text { Elders, the Elders to the } \\
\text { Prophets, the Prophets to } \\
\text { the Men of the Great } \\
\text { Synagogue, the Men of } \\
\text { the Great Synagogue to } \\
\text { Ezra the Scribe, Ezra the } \\
\text { Scribe to Hillel the El- } \\
\text { der, Hillel the Elder to } \\
\text { R. Abbahu, R. Abbahu } \\
\text { to R. Zira, R. Zira to } \\
\text { the Men of Faith, and } \\
\text { the Men of Faith to the } \\
\text { Faithful. }\end{array}$ \\
\hline
\end{tabular}

It is also noteworthy that the Enochic influences are now apparent not only in the end of this newly-constructed chain but also in its beginning, where the figure of the translated patriarch is hidden behind the name of the exalted angel Metatron who passes the initial revelation to Moses. In such a perspective the Mosaic successors and Moses himself represent only intermediate temporal guardians whose role is to pass the revealed knowledge into the hands of its true owners, the heirs of the Enochic tradition. ${ }^{16}$

${ }^{15}$ For the detailed analysis of this evidence see Swartz, Scholastic Magic... 178ff.

${ }^{16}$ In this respect 2 Enoch 35 operates with the concept of the «earthly guardians» (стражие Земмии) as the agents responsible for handling Enoch's writings until they finally are brought into the hands of the «Men of Faith». The expression «earthly 
An important detail of 3 Enoch's account is its anti-Mosaic flavor: the authors of the passage from Sefer Hekhalot try to diminish the importance of Moses and the transmitters of the Mosaic Torah by depicting the son of Amram in a role inferior to Enoch-Metatron from whom Moses receives his revelation. Scholars previously noted that this tendency to depict Metatron as a greater Moses was widespread in the Merkabah accounts. Several years ago David Halperin in his book The Faces of the Chariot ${ }^{17}$ demonstrated the popularity of such comparative imagery, which reflects the polemical character of the Merkabah portrayals of Moses and Metatron. He noted that in these materials Metatron is always depicted as «a greater Moses ... more exactly, he is Moses gone a step farther. Moses ascends to heaven; Metatron becomes ruler of heaven. Moses defeats the angels; Metatron dominates them. Moses grasps God's throne; Metatron sits on a throne identical to it. When Metatron grants revelation to Moses, he is giving a helping hand to his junior alter ego.... These authors ... saw the exalted Metatron as the primary figure, the ascending Moses as his junior replica». ${ }^{18}$

Halperin's work sees the initial background of the Merkabah polemical comparisons between the son of Amram and Metatron in Moses' ascension stories reflected in the rabbinic materials associated with the Shabuc ${ }^{c}$ t circle. ${ }^{19}$ He suggested that «as historians of the tradition ... we must reverse the relationships [between Moses and Metatron]. First the Shabucot preachers had Moses invade heaven and lay hold of the throne. Then the authors of the Hekhalot, breaking the restraints of the older stories, let Metatron enjoy the fruits of conquest». ${ }^{20}$

Still, despite Halperin's suggestions about the formative value and primacy of the rabbinic Shabucot testimonies for Moses-Metatron polemical interactions, it is possible that already in the Second Temple Enochic materials, namely in 2 Enoch, the Enochic authors attempted to portray the Mosaic hero as a junior replica of Enoch-Metatron.

In my previously published articles, I argued that 2 Enoch reveals an intricate web of the mediatorial debates in the course of which several traditions about exalted patriarchs and prophets prominent in the Second Temple Judaism, including Adam, Noah, and Moses, underwent polemical appropriation when their exalted features were transferred to the seventh antediluvian

guardians» might reflect a polemic with the Mosaic notion of the transmission and preservation of the revelation as «guarding». Among other places, such a concept is reflected in the famous rabbinic saying from $m$. Abot 1:1 where the preserving of the tradition is designated as «making the fence around the Torah».

${ }^{17}$ D. J. HalPERIN, The Faces of the Chariot: Early Jewish Responses to Ezekiel's Vision (Tübingen, 1988) (TSAJ 16).

${ }^{18}$ Ibid. 426.

${ }^{19}$ Ibid. $289 \mathrm{ff}$.

${ }^{20}$ Ibid. 426. 
hero. ${ }^{21}$ These polemical trends seem to reflect the familiar atmosphere of the mediatorial interactions widespread in the Second Temple period which offered contending accounts for the primacy and supremacy of their exalted heroes. The polemics found in 2 Enoch are part of these debates and represent a response of the Enochic tradition to the challenges of its exalted rivals.

In my previous work I tried to show that in 2 Enoch many theophanic features of Moses' story were transferred to Enoch. ${ }^{22}$ Two of such prominent characteristics are the motifs of the glorious face of the seventh antediluvian hero and his encounter with the Deity's hand during his celestial metamorphosis. Our study must now proceed to the investigation of these two motifs in 2 Enoch's materials.

\section{Luminous Face of Enoch}

From the Slavonic apocalypse one learns that the vision of the divine Face has dramatic consequences for Enoch's appearance. His body endures radical changes as it becomes covered with the divine light. In Enoch's radiant metamorphosis before the divine Countenance, an important detail can be found which further links Enoch's transformation with Moses' account in the Book of Exodus. In 2 Enoch 37 one learns about the unusual procedure performed on Enoch's face at the final stage of his encounter with the Lord. The text informs us that the Lord called one of his senior angels to chill the face of Enoch. The text says that the angel was «terrifying and frightful», and appeared frozen; he was as white as snow, and his hands were as cold as ice. With these cold hands he then chilled the patriarch's face. Right after this chilling procedure, the Lord informs Enoch that if his face had not been chilled here, no human being would have been able to look at him..$^{23}$ This reference to the dangerous radiance of Enoch's face after his encounter with the Lord is an apparent parallel to the incandescent face of Moses after the Sinai experience in Exodus 34. ${ }^{24}$

Exodus 34:29-35 portrays Moses after his encounter with the Lord. The passage relates that

Moses came down from Mount Sinai .... Moses did not know that the skin of his face shone because he had been talking with God. When Aaron and

${ }^{21}$ A. ORLov, «Noah's Younger Brother»: Anti-Noachic Polemics in 2 Enoch // Henoch 22.2 (2000) 259-273; IDEM, Melchizedek Legend of 2 (Slavonic) Enoch // JSJ 31 (2000) 23-38; IDEM, Noah's Younger Brother Revisited: Anti-Noachic Polemics and the Date of 2 (Slavonic) Enoch // Henoch 26.2 (2004) 172-187.

${ }^{22}$ A. OrLov, Ex 33 on God's Face: A Lesson from the Enochic Tradition // SBLSP 39 (2000) 130-147.

${ }^{23}$ Andersen, 2 Enoch... 160.

${ }^{24}$ Apoc. Paul 20 describes Enoch as the scribe of righteousness whose face shines «as the sun». 
all the Israelites saw Moses, the skin of his face was shining, and they were afraid to come near him... and Moses would put the veil on his face again, until he went in to speak with him.

This passage unambiguously constitutes the Mosaic background of the tradition found in 2 Enoch 37, where Enoch's face is depicted as similar to Moses' face who shields his luminous visage with a veil. The transference of the Mosaic motif into the framework of the Enochic tradition is made here for the first time. It is also obvious that this transferal has a polemical character. Passing on to the patriarch such a salient detail of the biblical story would immediately invoke in the Enochic readers the memory of Moses' example. Such transference also intends to demonstrate that Moses' encounter at Sinai and his luminous face represent later, inferior imitations of the primeval account of the patriarch's vision, a vision which occurred not on earth but in heaven in the antediluvian time.

The polemical appropriation of the Mosaic motif of the seer's radiant face is not confined in 2 Enoch solely to the encounter with the «frozen» angel, but is reflected also in other sections of the book. According to the Slavonic apocalypse, despite the chilling procedure performed in heaven, Enoch's face appears to have retained its transformative power and is even able to glorify other human subjects. In 2 Enoch 64:2 people ask the transformed Enoch for blessings so they can be glorified in front of his face. ${ }^{25}$ This theme of the transforming power of the patriarch's visage may also have a polemical flavor.

The theme of the luminous countenance of the seer is also important for the ongoing discussion of the Enoch-Metatron connection. It should not be forgotten that 2 Enoch's appropriation of the Mosaic imagery serves as the formative framework for the later Enoch-Metatron accounts, and especially for the one reflected in the so-called additional chapters ${ }^{26}$ of Sefer Hekhalot. In these chapters the theme of the luminosity of Moses' face and Metatron's visage are also put in a polemical juxtaposition. From 3 Enoch $15 \mathrm{~B}$ one learns that it is Enoch-Metatron, whose face was once transformed into fire, who tells Moses about his shining visage: ${ }^{27}$ «At once Metatron, Prince of the Di-

${ }^{25}$ See 2 Enoch 64:4 (the longer recension): «And now bless your [sons], and all the people, so that we may be glorified in front of your face today». ANDERSEN, 2 Enoch... 190.

${ }^{26}$ For a critical assessment of the theory of «core» and «additions» in Sefer Hekhalot, consult P. SCHÄFER, Handschriften zur Hekhalot-Literatur // IDEM, Hekhalot Studien (Tübingen, 1988) (TSAJ, 19) 228-229; P. ScHÄFER et al., Übersetzung der Hekhalot-Literatur. 4 vols (Tübingen, 1987-1995) (TSAJ, 17, 22, 29, 46) Vol. 1. LI.

${ }^{27}$ Scholars have observed that in the Merkabah tradition Metatron is explicitly identified as the hypostatic Face of God. See, for example, ScHÄFER, Synopse... §§ 396397: «...The Lord of all the worlds warned Moses that he should beware of his face. So it is written, "Beware of his face"... This is the prince who is called Yofiel Yahdariel... he is called Metatron». On Metatron as the hypostatic Face of God see A. DE 
vine Presence, said to Moses, "Son of Amram, fear not! for already God favors you. Ask what you will with confidence and boldness, for light shines from the skin of your face from one end of the world to the other" $\gg .{ }^{28}$ Here Moses is portrayed as a later version of his master Enoch-Metatron whose face and body were transformed into blazing fire long before the prophet's ascension at Sinai. ${ }^{29}$

\section{The Lord's Hand}

It is possible that the new theophanic imagery transferred to the Enochic hero in the Slavonic apocalypse might derive not only from the biblical accounts of the Sinai encounter, but also from the extra-biblical Mosaic stories in which the profile of the exalted prophet has a more advanced form. The authors of 2 Enoch may have been carefully following here the theological unfolding of the story of their rival and the enhancement of his profile as an elevated figure. The familiarity of Enochic authors with the Second Temple extra-biblical Mosaic accounts can be illustrated through an examination of the motif of the Deity's hand; this hand embraces and protects the seer during his encounter with the Lord in the upper realm.

In 2 Enoch 39 the patriarch relates to his children that during his vision of the divine Kavod, the Lord helped him with his right hand. The hand here is described as having a gigantic size and filling heaven: «But you, my children, see the right hand of one who helps you, a human being created identical to yourself, but I have seen the right hand of the Lord, helping me (помагахщоу

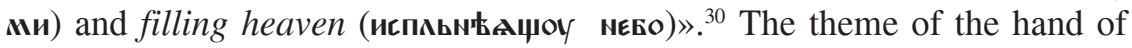
God assisting the seer during his vision of the Face recalls the Mosaic account from Exodus 33:22-23. Here the Deity promises the prophet to protect him with his hand during the encounter with the divine Panim: «and while

Conick, Heavenly Temple Traditions and Valentinian Worship: A Case for First-Century Christology in the Second Century // The Jewish Roots of Christological Monotheism / Eds. C. C. Newman, J. R. Davila, G. S. Lewis (Leiden, 1999) (JSJSup, 63) 329; HALPERIN, The Faces of the Chariot... 424-425.

${ }^{28} 3$ Enoch 15B:5. AleXAnder, 3 Enoch... 304. See also Raza Rabbah, where again a similar connection is made between Metatron's face and Moses' visage.

${ }^{29}$ SCHÄFER, Synopse... $§ 19$ (3 Enoch 15:1) depicts this radiant metamorphosis of Enoch-Metatron: «When the Holy One, blessed be he, took me to serve the throne of glory, the wheels of the chariot and all the needs of the Shekinah, at once my flesh turned to flame, my sinews to blazing fire, my bones to juniper coals, my eyelashes to lightning flashes, my eyeballs to fiery torches, the hairs of my head to hot flames, all my limbs to wings of burning fire, and the substance of my body to blazing fire». AleXANDER, 3 Enoch... 267.

302 Enoch 39:5. ANDERSEN, 2 Enoch... 162; Соколов, Славянская Книга Еноха Праведного... 1.38. 
my glory passes by I will put you in a cleft of the rock, and I will cover you with my hand until I have passed by; then I will take away my hand, and you shall see my back; but my face shall not be seen». There is also another early Mosaic account where the motif of the divine hand assisting the visionary is mentioned. The Exagoge of Ezekiel the Tragedian ${ }^{31}$ relates that during the prophet's vision of the Kavod, a noble man sitting on the throne beckoned

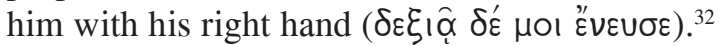

It is conceivable that 2 Enoch's description is closer to the form of the tradition preserved in Ezekiel the Tragedian than to the account found in Exodus since the Exagoge mentions the right hand of the Deity beckoning the seer. The passage from the Slavonic apocalypse also mentions the right hand of the Lord. Further there is another terminological parallel that unifies the two accounts. While the longer recension of 2 Enoch uses the term «helping» (помагадцио) in reference to the divine hand, some manuscripts of the shorter recension employ the word «beckoning» (помаваюџи), the term used in the Exagoge.

The terminological affinities between the Exagoge and 2 Enoch point to the possibility that the authors of the Slavonic apocalypse, in their development of the theme of the divine hand, were relying not only on the tradition preserved in Exodus but also on more advanced Mosaic speculations similar to those found in Ezekiel the Tragedian.

Although 2 Enoch's description is very similar to the Exagoge's passage, the Slavonic apocalypse has a more advanced version of the mystical image-

${ }^{31}$ This significant early testimony to the exalted profile of Moses has survived as a part of the drama Exagoge, a writing attributed to Ezekiel the Tragedian. The account depicts the prophet's experience at Sinai as his celestial enthronement. Exa-

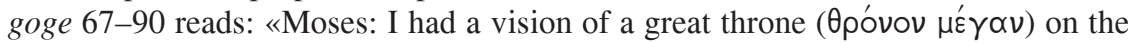
top of Mount Sinai and it reached till the folds of heaven. A noble man was sitting on it, with a crown and a large scepter ( $\left.\mu \dot{\varepsilon}^{\prime} \gamma \propto \sigma \kappa \hat{\eta} \pi \tau \rho \circ \nu\right)$ in his left hand. He beckoned to me with his right hand, so I approached and stood before the throne. He gave me the scepter and instructed me to sit on the great throne. Then he gave me a royal crown and got up from the throne. I beheld the whole earth all around and saw beneath the earth and above the heavens. A multitude of stars fell before my knees and I counted them all. They paraded past me like a battalion of men. Then I awoke from my sleep in fear. Raguel: My friend ( $\left.\hat{\omega}^{\prime} \varepsilon^{\prime} v \varepsilon\right)$, this is a good sign from God. May I live to see the day when these things are fulfilled. You will establish a great throne, become a judge and leader of men. As for your vision of the whole earth, the world below and that above the heavens - this signifies that you will see what is, what has been and what shall be». H. JACOBSON, The Exagoge of Ezekiel (Cambridge, 1983) 54-55. Wayne Meeks observes that, given its quotation by Alexander Polyhistor (ca. 80-40 B.C.E.), this Mosaic account can be taken as a witness to traditions of the second century B.C.E. W. Meeks, The Prophet-King: Moses Traditions and the Johannine Christology (Leiden, 1967) (SNT, 14) 149.

${ }^{32}$ JACOBSon, The Exagoge of Ezekiel... 54. 
ry; this imagery demonstrates close parallels to the symbolism of the Merkabah lore. The important detail here is that the divine hand is described as «filling

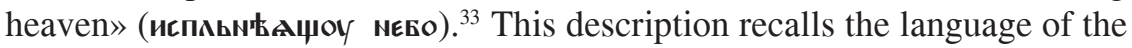
Shi 'ur Qomah accounts, in which Metatron reveals to Rabbi Ishmael and Rabbi Akiba the knowledge of the gigantic limbs of the Deity, limbs which fill heaven. It has already been noted that the allusion to this mystical imagery in the Slavonic apocalypse does not appear to be happenstance since it is incorporated there into a series of analogical comparisons between Enoch's body and the Lord's body. These portrayals recall the later Hekhalot and Shi ur Qomah accounts in which Enoch-Metatron is often portrayed as possessing the gigantic body himself.

The motif of the Lord's hand, prominent in the early Enochic account, is not forgotten in the Merkabah materials, where one can learn that «the hand of God rests on the head of the youth, named Metatron». ${ }^{34}$ The motif of the divine hand assisting Enoch-Metatron during his celestial transformation is present in Sefer Hekhalot, where it appears in the form of tradition very similar to the evidence found in the Exagoge and 2 Enoch. In Synopse $\S 12$ Metatron tells $\mathrm{R}$. Ishmael that during the transformation of his body into the gigantic cosmic extent, matching the world in length and breadth, God «laid his hand» on the translated hero. ${ }^{35}$ Here, just as in the Slavonic account, the hand of the Deity signifies the bond between the seer's body and the divine corporeality.

In Sefer Hekhalot the imagery of God's hand is also conflated with the Mosaic tradition. In Synopse § 68 Enoch-Metatron unveils to Rabbi Ishmael the hypostatic right hand of God with which «955 heavens were created». This introduction of the divine hand is interwoven in Synopse $\S \S 68-69^{36}$ into an elaborate set of references to Moses, to whom, according to the text, the mighty hand of God was once revealed. The author alludes to the passage from Isa 63:12, in which the Deity sends his glorious arm to be at Moses' right hand, as well as other Mosaic biblical themes. Although the name of the Israelite prophet is mentioned six times in this text, nothing is said about his exalted profile. It would seem appropriate there, since the main hero of this account is not Moses but the translated patriarch, who now unveils the mysteries of the divine hand to the visionary.

Moreover it seems that, in Synopse $\S \S 77-80,{ }^{37}$ Enoch-Metatron is understood, at least implicitly, as the hypostatic hand of the Deity himself. These

${ }^{33}$ Соколов, Славянская Книга Еноха Праведного... 1.38.

${ }^{34}$ SCHÄFER, Synopse... $\$ 384$.

35 «...the Holy One, blessed be he, laid his hand on me and blessed me with $1,365,000$ blessings. I was enlarged and increased in size until I matched the world in length and breadth». AleXANDER, 3 Enoch... 263.

363 Enoch 48A.

${ }^{37} 3$ Enoch 48D. 
materials depict the translated patriarch as the helping hand of God; with this helping hand God passes the Torah to the Mosaic hero and protects him against the hostility of angelic hosts.

After this short excursus into the theophanic polemical appropriations let us now return to our passage about the Men of Faith found in Sefer Hekhalot 48 where Enoch-Metatron is depicted as a revealer superior to Moses.

As I mentioned earlier, it appears that the main point of the polemical interactions in 3 Enoch 48 is to assert the supremacy of Enoch-Metatron as the revealer of Torah and the primacy of his revelation before the disclosure given to Moses. It is possible that the polemics about the primacy of the Enochic Torah before the Torah of Moses can be already seen in 2 Enoch, a text which in many ways anticipates Sefer Hekhalot developments and where one can find a similar terminology pertaining to the enigmatic group of the «Men of Faith» to whom the Enochic books will be eventually given.

\section{Enoch's Revelation}

The theme of Enochic revelation as the disclosure alternative to the Mosaic Torah looms large in chapters 24-32 of the Slavonic Enoch. In these chapters the reader encounters a lengthy narrative of God's revelation to the exalted patriarch about the seven days of creation. It depicts the Deity dictating to his celestial scribe, the patriarch Enoch, the account of creation organized in almost the same fashion as the first chapter of the biblical Genesis. The Lord starts his narration with the familiar phrase «in the beginning»: «Before anything existed at all, from the very beginning (исприва), ${ }^{38}$ whatever exists I created from the non-existent, and from the invisible». Although the very first line of the narration brings to memory the beginning of the Mosaic Torah, the creational account itself is quite different from the one reflected in the biblical Genesis. The story contains imagery pertaining to the primeval order and to the creation of humanity that is completely missing from the biblical text. Although the Enochic scribes try to preserve the structural grid of the Genesis story by organizing it around the seven days of creation, the plot is greatly expanded with new striking details and unknown characters, among whom one can find, for example, the cosmogonic figures designated as Adoil and Arukhas. The structure of this narration, involving the seven days of creation looks odd and disproportional in comparison with its biblical counterpart. Still, the composers of this peculiar version of the alternative Genesis ${ }^{39}$ try to hold on to the familiar organization that replaces

\footnotetext{
${ }^{38}$ Соколов, Славянская Книга Еноха Праведного... 1.24.
}

${ }^{39}$ The «alternative» thrust of 2 Enoch's creational account is so transparent that the editors of the Other Bible included this Enochic narrative as the non-canonical counterpart of the first chapters of Genesis. 
the memory of its Mosaic version. It is clearly fashioned as an alternative intended to overwrite an essential part of the Mosaic revelation. It is significant that despite the Enochic authors' attempt to deconstruct the well-known ancient account, the purported antediluvian reception of their disclosure speaks for itself, silently postulating the primacy of this revelation over the one received several generations later by Moses on Mount Sinai. It is also important that unlike in 1 Enoch, in the Slavonic apocalypse God reveals to the seer not simply astronomical information or a warning about the upcoming judgment, but a disclosure fashioned in form and structure similarly to the Mosaic Torah. The mode of reception is also different since the revelation is received not simply as a seer's dream, similar to the vision of the Biblical history in the Animal Apocalypse, but as directly dictated by God.

The chapters following the creation account in 2 Enoch 24-32 are also important for our discussion since they convey knowledge about the function and the future role of this alternative version of the first chapters of the Mosaic Torah. From 2 Enoch 33:8-12 one learns that the revelation recorded by Enoch will be transmitted from generation to generation and it will not be destroyed until the final age. The two following chapters (2 Enoch 34 and 35) also pertain to the themes of God's revelation to Enoch and the destiny of his books. The theme of the Enochic books is conflated here with the notions of the yoke and the commandments: after informing the seer that his handwritings and the handwritings of his ancestors will not perish in the upcoming flood, God reminds the seer about the wickedness of humans who have rejected the divine commandments and are not willing to carry the yoke (гармо $)^{40}$ which the Deity placed on them. It is curious that the terminology of «yoke» and «commandments» follows here the theme of Enochic writings. Scholars have previously proposed that the term «yoke» might be reserved here for the Torah. Celia Deutsch observes that «the yoke here refers to Torah, as is indicated by its use with "commandments" ». ${ }^{41}$ She also notes that this theme is further expanded in 2 Enoch 48:9, where it includes the teaching received by Enoch and transmitted through the revealed books. ${ }^{42}$ In 2 Enoch 48:9 the author of the Slavonic apocalypse is openly connecting the patriarch's scriptures with the notion of the «yoke», which serves here as an alternative designation for the Torah, ${ }^{43}$ the Torah of Enoch.

${ }^{40}$ Соколов, Славянская Книга Еноха Праведного... 1.34.

${ }^{41}$ C. Deutsch, Hidden Wisdom and the Easy Yoke: Wisdom, Torah and Discipleship in Matthew 11.25-30 (Sheffield, 1987) (JSNTSS, 18) 116.

${ }^{42}$ Ibid.

${ }^{43}$ It should be noted that although 2 Enoch 34 and 2 Enoch 48 use two different terms for «yoke» (2 Enoch 34 uses гармо and 2 Enoch 48 uses иго), both of these Slavonic words designate the same concept. Thus, Sreznevskij's dictionary relates

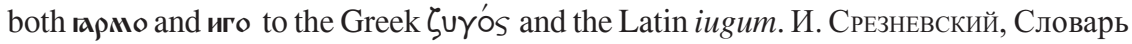




\title{
Conclusion
}

In view of the polemical interactions between Enochic and Mosaic traditions detected in the Slavonic apocalypse, one no longer needs to follow David Halperin's advice by clarifying the relationships between Moses and EnochMetatron on the basis of the later rabbinic testimonies to the Shabucot circle. Already in the Second Temple materials, specifically in 2 (Slavonic) Enoch, Enochic authors sought to portray the Mosaic hero as a junior replica of Enoch-Metatron and his revelation as the disclosure inferior to the one received by the seventh antediluvian patriarch. The passage from Sefer Hekhalot 48D:10 also attests to this long-lasting rivalry between Moses and Enoch. Yet in comparison with the author of 2 Enoch, the task of the Hekhalot author seems more complex - he cannot simply overwrite the Mosaic Torah, keeping silence about its revealer, as did the Enochic authors of the Slavonic pseudepigraphon. He must reconcile the two revelations. This is why in his version of the story, the Men of Faith become a link in the familiar Mosaic line of rabbis, sages, and prophets.

\begin{abstract}
2 Enoch 35 unveils a tradition according to which the Enochic writings will be eventually handled by the books' guardians to a group designated as the Men of Faith. The reference to the group as the last link in the chain of transmission of the Enochic scriptures recalls the terminology attested in the later «Enochic» material appended to some manuscripts of Sefer Hekhalot and known as Chapter 48D of 3 Enoch. In this account the revelation which is initially given by Enoch-Metatron to Moses passes through several transmissions into the hands of people named the Men of Faith. Scholars have previously suggested that this designation in the Hekhalot passage appears to function as a quasi-technical term for the mystics or their mythic ancestors. In this context the designation reflected in 2 Enoch may hold the key to the enigma of the Enochic group(s) standing behind the early Jewish mystical speculations.
\end{abstract}

древнерусского языка. 3 тома (Москва, 1989) Т. 1. 1019; Т. 3. 1663. Barchudarov's dictionary also lists the two terms as synonyms. Словарь русского языка XI-XVII веков / Ред. С. Г. БАрхудАров. 25 тт. (Москва, 1975ff) Т. 6. 78-79; Slovnik Jazyka Staroslovenskeho (Lexicon Linguae Palaeoslovenicae) / Ed. J. Kurz. 4 vols. (Prague, 1966) Vol. 1. 703. 